\title{
WHY WERE THE “ORIENTAL CULTS” INVENTED?
}

\begin{abstract}
Summary: The article is devoted to the analysis of the historiographical background of the category of the so-called oriental cults/oriental religions created in the $19^{\text {th }}$ century and developed by Franz Cumont. We discuss the role of this term in $20^{\text {th }}$-century historiography with the focus on the works of Tadeusz Zieliński that are important to the reception of the oriental cults metaphor. We argue that the concept of oriental cults/oriental religions in its original version is not an effective or useful research tool. However, as a historiographical concept it has fulfilled its role in a threefold way: firstly, it drew scholars' attention to the vitality of ancient religious experience, secondly, it established the fact that Roman religion was a living organism, naturally adapted to changing political, social and cultural conditions, thirdly, it helped to understand the principles behind the construction of metaphors in the academic discourse.
\end{abstract}

Key words: postcolonial theory, historiography, orientalism, Franz Cumont, Tadeusz Zieliński, oriental religions, religions of Roman Empire

Research on the religion of ancient Romans has a long history and, as is so often the case in the humanities, its scope and theoretical and methodological borders are closely connected to research assumptions from outside academia. To paraphrase Albert Henrich's formula, expressed in the brilliant study on the borders of the history of ideas, historiography and - as we might call it - the psychopathology of academic life, concerning Dionysius and his image in the humanities from Nietzsche to Girard, we can conclude that "the term is more than the sum of its components".

May this statement become the base of our further investigations of "oriental cults". The comments below have a double nature. On the one hand, we stand firmly on historiographical ground when we analyse the use of the term by certain researchers.

${ }^{1}$ Henrichs, A.: Loss of Self, Suffering, Violence: The Modern View of Dionysus from Nietzsche to Girard. HSCPh 88 (1984) 205-240, here 234. 
On the other hand, however, we attempt to describe the theoretical and methodological boundaries which have divided and still divide historians of ancient religions.

The concept of "oriental religion" is inseparably linked with the name of Franz Cumont (1868-1947), and his book, Les religions orientales dans le paganisme romain. The work, published in 1906, immediately gained publicity and acclaim, a measure of its success being subsequent editions, translations and numerous reviews, making it - throughout most of the 20th century - the main reference point for anyone writing about religion in the Roman Empire. ${ }^{2}$

The $50^{\text {th }}$ anniversary of the death of Cumont and the $100^{\text {th }}$ anniversary of the first edition of the work were honoured with numerous conferences and seminars, and above all a re-edit of the text. ${ }^{3}$ The aftermath consisted of a host of publications containing reflections, among others, on the concept of "oriental religion" both as a historical category and a research tool, which although questioned for many years, still has its supporters and defenders. ${ }^{4}$ Richard Gordon, in a review of one of the annual publications wrote that it is a "continental response" to the fact that the concept of "oriental religion" had been effectively cast aside by English and American researchers during the second half of the $20^{\text {th }}$ century. ${ }^{5}$ Gordon considers the symbolic beginning of this process to be the commentary of Ramsay MacMullen, who referred to Cumont, not without certain maliciousness, as "the high priest of «oriental cults»". 6

The question of the part played by eastern cults in the religious transformation of the ancient world has provoked the interest of many researchers within French academic circles, whose opinions had a significant influence on Cumont's intellectual formulations. The most important was probably the Hebraic researcher Ernest Renan. In the last volume of Histoire des origines du christianisme, dedicated to the period of Marcus Aurelius (1882), he wrote that Christianity owed its success to the new model of life connected with expectations of moral renewal and deepened relationships with the gods, but already by the end of the $2^{\text {nd }}$ century neither philosophy nor religion were able to fulfil these needs. The weakness of the gods of traditional mythology was caused by a universal turn towards the cults of oriental gods with their new messages. Renan was already drawing attention to elements which, in his opinion, were common to eastern cults, as Cumont later developed. ${ }^{7}$ The term "oriental religion" appears in

2 VAN HAEPEREN, F.: La réception des Religions orientales de Fr. Cumont : l'apport des comptes rendus. Anabases 6 (2007) 159-185. https://doi.org/10.4000/anabases.3360

${ }^{3}$ CUMONT, Fr.: Les religions orientales dans le paganisme romain. Éd. par C. Bonnet et Fr. Van Haeperen avec la collaboration de B. Toune [Bibliotheca Cumontiana Scripta maiora]. Torino 2006.

${ }^{4}$ Alvar, J.: Romanising Oriental Gods. Myth, Salvation and Ethics in the Cults of Cybele, Isis and Mithras. Leiden-Boston 2008; MACRIS, C.: La réception de Franz Cumont : à propos de quelques publications récentes. Anabases 18 (2013) 215-226. https://doi.org/10.4000/anabases.4371; MACRIS, C.: La réception de Franz Cumont : à propos de quelques publications récentes II. Anabases 19 (2014) 251278. https://doi.org/10.4000/anabases.4698

${ }^{5}$ Gordon, R. L.: Coming to Terms with the "Oriental Religions of the Roman Empire". Numen 61 (2014) 657-672. https://doi.org/10.1163/15685276-12341346.

${ }^{6}$ MacMullen, R.: Paganism in the Roman Empire. New Haven 1981, 116.

${ }^{7}$ Rouselle, A.: La transmission décalée. Nouveaux objets ou nouveaux concepts? Annales 44 (1989) 161-171; Bonnet, C. - Pirenne-Delforge, V. - Praet, D. (eds): Les religions orientales dans le 
La Religion à Rome sous les Sévères published in 1886 by Jean Réville, who, similarly to Renan, located the source of the popularity of eastern gods in the inability of the traditional Greek-Roman pantheon to fulfil new religious needs. ${ }^{8}$

Franz Cumont was not, then, the first to write about oriental religion, but without doubt his main contribution was the introduction of this concept into the sphere of academia. In the introduction to Les religions..., he wrote that next to the success of neo-Platonic philosophy, the spread of oriental cults is a fact of most crucial significance in the moral history of the pagan imperium. ${ }^{9}$ In another sentence he emphasises that the invasion of these cults destroyed traditional religious values and led to a deep transformation of the Roman state and society. ${ }^{10}$ On the next pages of the book we find Cumont's reflections on the subject of the causes and methods of the spread of the oriental cults in the Roman world. This phenomenon was introduced in a geographical sense with a division into cults coming from Asia Minor, Egypt, Syria and Persia, and in a "genetic" sense, that is to say introducing the birth, development and disappearance of the cults. It is worth remembering that Cumont, like Renan, was primarily interested in the causes of the triumph of Christianity in the ancient world, and this is the issue which drives the narration of Les religions.... In the chapter concerning the transformation of paganism he assigned a destructive role to them as far as traditional Roman religion was concerned, although he devotes much less attention to this issue than his predecessors. Given the fact that the term oriental had never been used in a religious context, it is slightly puzzling how easily it slid into everyday use. Cumont, similarly to Renan, was interested above all in the causes of the triumph of Christianity in the ancient world and he dealt with this question in Les religions.... Describing the process of expansion of the cult of eastern gods in the Imperium, he concentrated predominantly on those elements which according to him had eased the transition from paganism to Christianity and helped lead to the triumph of the latter. "11 "Triumph" in relation to Christianity and "fall" in relation to paganism were two terms introduced into common use by the German historiography at the end of the $19^{\text {th }}$ century.

Despite the fact that the objects of interest for Cumont were cults of various provenances, histories and cult practices, like Cybele, Sarapis and, above all, Mitra, he mainly concentrated on exhibiting the often extremely doubtful similarities between them, ignoring facts which were uncomfortable for his theory. ${ }^{12} \mathrm{He}$ considered common points to be the spectacular ceremonies engaging the emotions of the believers and the existence of "clergy" creating a "congregation". The Misteria with its promise

monde grec et romain : cent ans après Cumont (1906-2006) : bilan historique et historiographique. Colloque de Rome, 16-18 novembre 2006. Brussels 2009; TURCAN, R.: Les cultes orientaux dans le monde romain. Paris 1989.

${ }^{8}$ RÉVILle, J.: La Religion à Rome sous les Sévères. Paris 1886.

${ }^{9}$ Cumont (n. 3) vii: "le fait capital de 1 histoire morale de l'empire païen".

${ }^{10}$ Cumont (n. 3) 29: “l'invasion des cultes orientaux, qui détruisit l'ancien idéal religieux et national des Romains, transforma aussi profondément la société et le gouvernement de l'Empire".

${ }^{11}$ Cumont (n. 3) 16.

12 BURKERT, W.: “Orient” since Franz Cumont: Enrichment and Dearth of a Concept. In BonNET - Pirenne-Delforge - Praet (n. 7) 105-117. 
of some form of existence after death was, for Cumont, a deep spiritual religious experience, much more attractive than the official religion of the Roman Empire. About the latter, he wrote that it did not fulfil the expectations of the people, since it was cold, prosaic and subject to detailed legal prescriptions. ${ }^{13}$

The concept of "oriental religion" in the form proposed by Cumont owes much to the late ancient Christian authors who "thought up" the literary image of the pagan. It was they, after all, who made up the literary image of paganism as a reasonably monolithic organisational and doctrinal system, that is, something you might call the "antithesis of Christianity". This particular vision of a unified pagan organisational and doctrinal system includes, for example, the treatise De errore profanarum religionum by Firmicus Maternus. Aude Busine, following in the footsteps of Robert Turcan, prepared a discussion of motives in the text of the Christian apologists who had a deciding influence on Cumont's concept of "oriental religion". ${ }^{14}$ The most important of these was the destruction of Roman religion and its substitution with an "invasion" of gods from the East and oriental gods, as rivals to Christianity.

Cumont's views cannot be judged in isolation from the academic and cultural realities of the $19^{\text {th }}$ century, dominated by the history of evolutionism, with its dependence on Hegel. Within the history of religion an obligatory view was held that the natural way of development is transformation from polytheism to monotheism. Cumont saw in the cults which came from the east an indispensable link between these two systems. Evolution was for him a synonym of progress, which in the religious sphere was expressed predominantly in the moral dimension, and led to the replacement of the cults of traditional gods by new forms of religiosity, based on individual bonds with the gods. He was convinced that "oriental religions" dealt the final blow to Roman religion, which was finished off with that same "triumph" of Christianity. It is worth noting that such research assumptions, which can be fitted into the formula: invasion - settlement - resistance - revolt - new quality, enable them to be analysed within the categories of post-colonialism. ${ }^{15}$

This understanding of "oriental religions" was still the object of research, many years after Cumont's death, and the effects were published in the series Études préliminaires aux religions orientales dans l'Empire romain, started up in 1961 by Maarten J. Vermaseren. The deconstruction of the "Cumont-Vermaseren" model was helped along by researchers of the ancient world who were enlivened by the reception of Edward Said's Orientalism, which was published in 1978, and for a dozen or so years set the tone of discussion on the issue and defined post-colonial studies. ${ }^{16}$ Said's great service was to draw attention to the discursive character of the image of the Orient in European culture. In the research practice this means the creation of an identity for the Orient and treating it as a reflection of reality. Unfortunately this work was not treated with the

${ }^{13}$ Cumont (n. 3) 20-22, 381.

${ }^{14}$ TuRCAn (n. 7) 14-15; Busine, A.: De Porphyre à Franz Cumont. La construction des religions orientales par Firmicus Maternus In BONNET - PIRENNE-DELFORGE - PRAET (n. 7) 413-426.

${ }^{15}$ Bullock, A. V.: Eleusis as Palimpsest: Postcolonial Theory and the Politics of Religion in Roman Greece. Diss. Emory University 2010, 8.

${ }^{16}$ SAID, E.: Orientalism. New York 1978. 
attention it deserved by the community of academic researchers of the ancient world. ${ }^{17}$ In any case, Said's reflection, that the "grammar of the discourse about the orient that was related to but not synonymous with the orient itself", caused a paradigm shift in contemporary understanding of oriental religion. ${ }^{18}$ An example of this is the fact that at the beginning of the ' 90 s editors withdrew this title, which had become controversial, in favour of the more neutral description Religions in the Graeco-Roman World.

The end of the last century brought many new findings and methodological innovations in research on the religious transformations of the Roman Empire. One important effect was the deconstruction of the concept of "oriental religions", which was considered to no longer fit the present state of knowledge about the source and nature of the cults described in Les religions.... The most important criticisms of Cumont's theory can be boiled down to a few points. Firstly, the category he invented, "oriental religions", is an anachronism, since it had no meaning for the Romans themselves. Secondly, exhibiting supposedly common sources, Cumont assumed that after spreading in the West they preserved their eastern character, and omitted to take into account the mediation of Greece and the process of Hellenisation. The third and final criticism concerns the illusions, shared by Cumont and his contemporaries, that the cults included within "oriental religions" created a homogeneous group. Today we have no more doubts that under Cumont's categories lie hidden cults which differed in their cult practices, imaginings of the gods, and degrees of personal engagement on the part of the worshippers. The origins of the gods did not matter, since the forms of the cults preserved in the sources had formed already in the Hellenised East, and not in the mythical Orient, which was discussed in the $19^{\text {th }}$ century.

Cumont's concept was not only a derivative Christian-centric religious vision of history, which privileged Christian religious experience as a set of norms which were not open to discussion - it was also based on a colonial vision of the Orient. One of its elements is the omission of differences. Cumont's Orient was very wide, covering Egypt, Syria, Anatolia, Palestine and Persia, that is lands with different histories and extremely differing religious traditions. Another significant element of this vision is the treatment of religion as a dominant tool, marginalising and even omitting its significance as a cultural reality. ${ }^{19}$

"The spirit and mysticism of the Orient gradually overtook the whole community and prepared everyone to unite within one universal Church", wrote Cumont in the sentence which closes Les religions.... ${ }^{20}$ But the image of the East evoked by his discussion is not as unambiguous as the cited sentence might imply. Alongside the fascination with the soteriological aspects of mystery cults, treated as a link between the pagan and Christian ancient worlds, we find in Cumont an irrational East, whose gods and their

17 Versluys, M. J.: Orientalising Roman Gods. In Bricault, L. - Bonnet, C. (eds): Panthée. Religious Transformations in the Graeco-Roman Empire. Boston-Leiden 2013, 235-261, here $236-241$.

18 SAid (n. 16) 22; BUllock (n. 15) 17.

${ }^{19}$ VERSLUYS (n. 17) 235-261.

${ }^{20}$ Cumont (n. 3) 328: "L'esprit religieux et mystique de l'Orient s'était peu à peu imposé à la société entière, et il avait préparé tous les peuples à se réunir dans le sein d'une Église universelles". 
faithful constitute the antithesis of the rational culture of the West. ${ }^{21}$ This dualism in perceptions of the East is deeply rooted in the $19^{\text {th }}$-century tradition. The opposition of East and West in different variations and contexts characterised literary discourse as well as theological, philosophical and historical debates. The Hegelian vision of history played an important part in the construction of this image, with its linear structure of diffusion of civilisation from East to West, from Asia to Europe, through Greece and Rome, and German philology from the start of the century with Friedrich Creuzer at the head, and his image of the Orient as the source of myths and religions. ${ }^{22}$ Ernest Renan took a different position, perceiving the East very narrowly (against the established tradition of the $19^{\text {th }}$ century), and concentrating his research on Palestine and Arabia. The remainder of the 'East' for him was the breeding ground for freakish religiosity and disgusting rituals (as he described taurobolium). In the same way, Renan could be seen as the symbolic patron of the conception of the superiority of the West over the East, with its inbuilt political and religious dimensions. ${ }^{23}$ This colonial discourse is itself a part of the colonial system. Cumont did not share his risky assumptions, he was closer to the opinions of J. G. Droysen expressed in Geschichte des Hellenismus (1836), which portrayed the Orient as an area of developed civilisation.

We would like to contrast the opinions of Franz Cumont, the widely known researcher, with the concepts of another academic, whose achievements in the field of the history of ancient religions have been almost entirely forgotten, namely Tadeusz Zieliński (1859-1944). ${ }^{24}$ There is much to link the two researchers. We see an interesting example of the reception of Cumont's views in the eastern European academic environment and despite all their differences, they held a similar view of the object of research. We might describe it as "theological" or "teleological", because according to both scholars its natural fulfilment was Christianity. Both scholars treated the object of their studies as a history of the evolution of moral ideas. ${ }^{25}$ In the vision of ancient religions presented by the Belgian scholar we can find elements very far from the introduced Hegelian opposition of the Greek religion of beauty and the Roman religion of common sense and law. The publishers of Les religions... noticed that the philosophy of Hegel was an example "d'une histoire «theologique», donc «progressiste»". ${ }^{26}$ Hegel, a representative of idealism, also wielded a strong influence on Zieliński, who

${ }^{21}$ BEndlin, A.: „Eine wenig Sinn für Religiosität verratende Betrachtungsweise“: Emotion und Orient in der römischen Religionsgeschichtsschreibung der Moderne. AfR 8 (2006) 227-256.

22 Borgeaud, P.: L'Orient des religions. Réflexion sur la construction d'une polarité, de Creuzer à Bachofen. AfR 8 (2006) 153-162.

${ }^{23}$ Simon-Nahum, P.: L'Orient d'Ernest Renan : de l'étude des langues à l'histoire des religions. Revue Germanique Internationale 7 (2008) 157-168. https://doi.org/10.4000/rgi.406

${ }^{24}$ Short introduction into Zieliński's work: GillmeIster, A.: The Point of View. Tadeusz Zieliński on Ancient Religions. Warsaw 2013.

${ }^{25}$ CUMONT (n. 3) 6; ZIELIŃSKI, T.: Elementy wschodnie w religiach świata antycznego [The Eastern Elements in the Religions of Ancient World]. In Religie Wschodu. Warszawa 1939, 437-460; cf. PRAET, D.: Oriental Religions and the Conversion of the Roman Empire: The Views of Ernest Renan and of Franz Cumont on the Transition from Traditional Paganism to Christianity. In ENGELS, D. - VAN Nuffelen, P. (eds): Religion and Competition in Antiquity. Brussels 2014, 285-307, here 294.

${ }^{26}$ Bonnet, C. - VAn HAEPEREN, F.: Introduction historiographique. In CUMONT (n. 3) xxiii. 
in contrast rejected Renan's ideas, maybe with regard to ideological factors (the Polish scholar was known for his ardent, though utterly unorthodox, godliness).

Zieliński treats the "East" as a collective term, comprising several nations and cultures, partly independent of each other. They had effects on Roman religion either directly, or through Greek religion. The question which the researcher attempts to answer concerns the nature of the relationship of the Greek-Roman world to the religions of the widely defined East.

The answer to the problem, so stated, works in two ways. On one hand, Zieliński draws attention to the complete Hellenisation of some of the cults, caused inter alia by Homer. According to the Polish scholar, in the Illiad the Great Mother of the Gods lay beneath the character of Aphrodite. Zieliński consistently refers to Cybele by this description, sometimes using the different title of Great Idaean Mother of the Gods. He sees, however, a distinct difference in the variants of the cult of Magna Mater and the gradual level of Hellenisation. ${ }^{27}$ It is worth drawing attention to the terminological issue. In reference to beliefs treated as eastern, he uses the terms "cult" and "religion" interchangeably. This goes somewhat against the contemporary tendency in religious studies, which tries to describe the terminology used in the newly arisen field of study precisely. It is in total accordance, however, with the ancient understanding of these concepts. It should be noted that in the cases of Zieliński and Cumont, the titles of their main works contain a clear methodological manifesto. Both scholars were interested in "religion" as an entirely Christianised concept. In addition, the subtitle of Cumont's work unambiguously outlines his area of interest, that is, "Roman paganism". In other words he was interested in the influence that "oriental religions" wielded on the Roman religious system, and Judaism and Christianity lay beyond the scope of his attention. ${ }^{28}$ This deserting of the Judeo-Christian tradition, according to plan (although of course he referred to it in the course of his narration) further underlines his use of a Christianised, or - in this context - a colonial discourse.

Zieliński differentiates two directions within the expansion of eastern cults in Rome. ${ }^{29}$ Firstly, he points out the popularity of oriental holiness amongst women, and connects this with the number of slaves coming from the East. Women, to whom the scholar attributed only domestic tasks, spent time with servants celebrating rituals which were interesting from a Roman point of view, and submitted to the alluring influence of oriental religions. Secondly, in his opinion the way to the "orientalisation" of Roman religion through "hellenisation" was paved by the activities of the soothsayer Sibyl. It appears that Zieliński saw "oriental religion" more clearly than Cumont as, to a large extent, a cultural construct based on interaction between the Latin and Hellenic parts of the Empire.

Eastern cults were for Zieliński, similarly to Cumont, above all of a mystery religious nature and it is from this angle that he interpreted the cult of the Great Mother of

\footnotetext{
${ }^{27}$ Cf. ZIELIŃSKI, T.: Religia cesarstwa rzymskiego [Religion of Roman Empire]. Toruń 1999, 503-504.

${ }^{28}$ PRAET: Oriental Religions (n. 25) 286.

${ }^{29}$ ZIELIŃSKI: Elementy (n. 25) 448.
} 
the Gods. He showed, however, ambivalent feelings in relation to the forms of holiness he described, as confirmed by his relationship to the practices of taurobolium. On the one hand, he perceived meaning in this mystical ritual and intuitive seeking for purification from sins in the hope of gaining eternal life. On the other hand, he considered it to be "disgusting". 30 "The way could be mistaken but the goal was good", as he put it. ${ }^{31}$ Renan and Cumont were of a similar opinion, and Zieliński shared their aversion to ceremonies in honour of the "oriental" gods, but he valued the eschatological aspect of the cults. He was, after all, similarly to Cumont, convinced that the "theology" of the oriental cults that he described with barely hidden scorn, contained the key to eternal life. They also prepared the way for the arrival of Christianity, in which Zieliński saw the true coronation of the ancient religions. He noticed that along with the growth in popularity of oriental religions their authority also grew. This enabled a kind of holiness to be glimpsed which could quench the thirst for redemption. This approach to the object of research, full of disquiet mixed with a striving for its "domestication" is characteristic of the colonial discourse, based amongst other things upon the understanding of difference from a position of superiority. This appears in the tendency, amongst others, to use the quantifiers "true", "false", "distorted" religion, custom, etc. The researchers usurped their right to use the language of a concept which is on the one hand stabilising and on the other highly persuasive. ${ }^{32}$

Zieliński, in contrast to Cumont, placed oriental religions in the context of civic religion. He sometimes underlined the differences between them, with a certain rhetorical exaggeration, only to minimise them in other places. Every time, however, even in the case of the castrated priests of Cybele, he tried to place the experiences of faithful believers within the framework of Roman religious experience. He emphasised the moral dimension of the cult of Mithra, appearing in the Mithraic mysteries, but he considered it to be the effect of later changes which Mithraism underwent in the Greek-Roman world. The acculturation of oriental religions into Roman religious experiences in the form presented by Zieliński was a result of the way in which the scholar described the development of civic religion, placing emphasis on the layers appearing in it. During the period of the Roman Empire the eastern "layering" even if it led to a temporary orientalisation of civic religion, as took place during, for example, the reign of Heliogabalus, was sooner or later rejected or Romanised. ${ }^{33}$ An example of this kind of activity is the solar religion propagated by the Emperor Aurelius. Thanks to it the pagan religion of Rome entered its last phase before "conversion" to Christianity.

Franz Cumont viewed Roman religion in political categories, i.e. as a function of the state. The task of religion, understood as such, was to maintain the state of balance between the gods and the people, and not necessarily to ensure living contact with the gods. This opinion could be considered as one of the few similarities to the picture

${ }^{30}$ ZIELIŃSKI: Elementy (n. 25) 455.

${ }^{31}$ ZIELIŃSKI: Religia (n. 27) 250.

${ }^{32}$ BOTTA, S. - FERRARA, M.: Introduction. SMSR 82.2 (2016) 527-536, here 531-532.

${ }^{33}$ ZIELIŃSKI, T.: Rom und seine Gottheit. In ZIELIŃSKI, T.: Iresione t.2. Dissertationes ad antiquorum religionem spectantes continens [Eus Supplementa 8]. Leopoli (Lwów) 1936, 111-153. 
of Roman religion painted by Georg Wissowa. In Les religions..., Cumont stated that Roman religion was cold and prosaic. In opposition to it, the cults of the east, with their expanded emotionality, the splendour of their ceremonies and the aura of mystery around them, lured new believers. ${ }^{34}$ Was the Belgian scholar a supporter of Wissowa's thesis on "Verfall der Staatsreligion", though? It might be considered so on the surface, as he wrote that after the fall of the Republic indifference to religion spread, the temples emptied and once popular religious ceremonies were forgotten. Even Augustus' reforms were not successful, as they were attempts to enliven a dying religion for political reasons. But Cumont's meaning was closer to an "exhaustion of the formula" offered by the legitimising state cults, than an evolutionary road to downfall. Honouring the Roman gods was a citizen's duty, and honouring gods from outside the official pantheon - a personal choice. ${ }^{35}$ Cumont noticed that hidden work was occurring in the religious sphere, based on the "exchange" of the parts of Roman religion that fell victim to atrophy with elements originating from the east which infused their believers with new vigour. In fact the religion which remained was completely different from the one which Augustus had tried to renew, but was it due to this any less Roman? ${ }^{36}$ This argument is strengthened by the fact that apart from Cumont's interests there were also issues of the origins of religion, which was distinctly different from the approach Wissowa propagated. A lack of engagement in genesis/origin research meant also a lack of interest in defining the beginning of the fall of state religion. Despite the rejection, or maybe rather the lack of interest in the "Dekadenzidee", Cumont shared with Wissowa - with whom he corresponded from 1888 - a linear, and even teleological vision of religious evolution in the Roman Empire, "de la Staatsreligion aux cultes orientaux, et de là aux christianisme". ${ }^{37}$ Tadeusz Zieliński fully shared this opinion. Oriental religions take on, in this case, a hybrid form. On one hand, no longer a state religion, on the other, not Christianity yet.

Zieliński referred in his writings to the category of psychological continuity, stating many times that the peak of religious striving in the western world is Christianity, in which the tendency shown by the believer to express religious feelings in a form ever more perfect intellectually, aesthetically and ethically, came to its ultimate fruition. ${ }^{38}$ Through the above-mentioned differences in understanding of Roman religion, in the times of Symmachus and Praetextatus there was not much difference in the understanding and living of religious experience between polytheism and Christianity. ${ }^{39}$ And the spiritual and mystical soul of the Orient slowly soaked through all layers of society and prepared the people of the Empire to be united in a common church.

In answering the question posed in the title: why were the "oriental cults" invented, we would like to emphasise one point, once more. Despite the fact that in the

${ }^{34}$ Cumont (n. 3) 66.

35 Cumont (n. 3) 67.

${ }^{36}$ CUMONT (n. 3) 302.

${ }^{37}$ BONNET - VAN HAEPEREN (n. 26) xxix.

${ }^{38}$ On "psychological continuity", see ZIELIŃSKI, T.: Erudition und Gefühl. In Iresione (n. 33) 490-479; ZIELIŃSKI, T.: La Sibylle. Trois essais sur la religion antique et la christianisme. Paris 1924.

${ }^{39}$ Cumont (n. 3) 14. 
contemporary literature the concept of "oriental cults" is often used as a binding term, understood intuitively, its strong ideological undertones cannot be denied. As we have tried to present, this ideology could have come from several sources. Some are rooted for example in the work of the Belgian Franz Cumont, and others in the work of the Polish Tadeusz Zieliński, for whom the term "Orient" had a slightly different meaning, as a result of Poland's historical experience. The geopolitical fluidity of the concept undoubtedly requires careful analysis and, at the same time, epitemic revision. ${ }^{40}$

The term "oriental cults" enabled researchers who used it to search for Christian religious experience within ancient religion. Franz Cumont and Tadeusz Zieliński, whose views form the base of our analysis could be considered intuitive phenomenologists. Both scholars tried to research religious phenomena, and especially the category, fashionable at the turn of the $19^{\text {th }}$ and $20^{\text {th }}$ century, of religious experience popularised by William James in the Gifford lectures. In the case of our protagonists we are dealing with comparable ideas treated as examples of phenomena which do not change over time and are possible to understand, and even to feel, two thousand years later. This ahistorical, or rather transhistorical approach to the source material eventually had to result in a loss of perspective. It is hard though to accuse them of this. In fact, until the 1970s phenomenological understanding was the basic and seemingly natural approach to religious issues and only relatively recently have wider research perspectives been taken, out of which for our purposes the most interesting is the postcolonial approach. ${ }^{41}$ Use of this paradigm does not refer to the subject of Cumont's and Zieliński's research but to the analyses, and to the ideological and academic context within which they arose.

Many contradictions can be found in Cumont's and Zielinski's thoughts on oriental religion. The scholars tended to lead their discourses in such a way that most of these contradictions could be nullified or minimalised. This did not always work though, because this was not always their aim. Daniel Praet listed a few of the contradictions shared by both scholars. On the one hand, oriental religions conquered the western part of the empire, bringing emotions to the religious experience of the Romans and introducing the concept of gods which were closer to their followers. On the other hand, however, he emphasised the irrationality and fanaticism of the eastern beliefs. Traditional religion was introduced in a similarly antithetical way - repressive and cold, while containing a space of freedom. ${ }^{42}$ The "disaster" which occurred while trying to reconcile these contradictory ideas is the next signal pointing to our description of their discourse as colonial. According to Homi Bhabha, next to Said probably the most significant representative of postcolonial theory, ambivalence is the basic term of analysis for colonial discourse. ${ }^{43}$

40 BOTTA-FERRARA (n. 32) 527.

${ }^{41}$ Jensen, J. S.: Is a Phenomenology of Religion Possible? On the Ideas of a Human and Social Science of Religion. Method \& Theory in the Study of Religion 5 (1993) 109-133.

${ }^{42}$ PRAET: Oriental Religions (n. 25) 293; cf. BONNET, C.: "L'Histoire séculière et profane des religions" (F. Cumont): Observations sur l'articulation entre rites et croyance dans l'historiographie des religions de la fin du XIXe et de la première moitié du XXe siècle. In SCHEID, J. (dir.): Rites et croyances dans le religions du monde romain. Entretiens sur l'antiquité classique. Tome LIII. Vandoeuvres-Genève 2007, 1-28, here 9 .

${ }^{43}$ BULLOCK (n. 15) 43. 
At the same time, maybe somewhat paradoxically, the term "oriental cults" enabled the originality of the religions of ancient Rome to be valued, and it was a partially successful attempt to break through the trend, reigning at the time, of putting Greek culture and religion first. A Hellenistic view of the ancient world and a romantic consideration of the affinity between the Greek and the contemporary soul were characteristic mainly of German academia. This is probably where the omission of the role of Greece and Hellenisation practices in the transfer of cults and rituals comes from. In their rejection of the projection of ancient Greece as the ideal cultural past and consequently the ideal religious experience, Cumont and Zieliński created the base of a new understanding of the religion of Imperium Romanum. This does not mean, however, that they went beyond the idealist perspective, which from the times of Hegel and Schleiermacher exerted a vital influence on the intellectual constitution of research on the ancient world. Frank Ankersmit, the influential historiographical theorist, wrote that "criticizing metaphors on factual grounds is indeed an activity which is just pointless as it is tasteless. Only metaphors «refute» metaphors". ${ }^{44}$ It seems to us that this is another reason not only for the invention, but also the great vitality of the term "oriental religions" in the European literature. Treating this term as a metaphor we can state that next to "Verfall der Staatsreligion" it was one of the most attractive metaphors serving to describe ancient religious experience in categories which are comprehensible to Europeans of the $19^{\text {th }}$ and $20^{\text {th }}$ centuries. At the close it is worth emphasising one more point - the concept of "oriental religions" in its original version is not an effective or even useful research tool. However, as a historiographical concept it has fulfilled its role in a threefold way. First of all, it sensitised academics writing in the last few decades to the vitality of ancient religious experience. Secondly, it established the fairly obvious fact, from the point of view of anthropological and religious studies, that Roman religion was a living organism, naturally adapted to changing political, social and cultural conditions by the construction of categories to tame the foreignness of new members of the community. ${ }^{45}$ Thirdly, it enabled those who had been engaged with the world of Roman religion over the last 20-30 years to understand the principles behind the construction of metaphors in the academic discourse, and to notice the dangers connected with their overuse. Nomen est omen.

\author{
Andrzej Gillmeister \\ University of Zielona Góra \\ a.gillmeister@ih.uz.zgora.pl \\ Danuta Musiał \\ Nicolaus Copernicus University, Toruń \\ dmusial@umk.pl
}

\footnotetext{
${ }^{44}$ Ankersmit, F. R.: History and Tropology. The Rise and Fall of Metaphor. Berkeley - Los Angeles - London 1994, 180.

${ }^{45}$ Cf. SCHEID, J.: Graeco ritu: A Typically Roman Way of Honouring the Gods. HSCPh 97 (1995) 15-34; Versluys (n. 17); GillmeISTER, A.: Cultural Paraphrase in Roman Religion in the Age of Augustus. The Case of the Sibyl and the Sibylline Books. AAntHung 55 (2015) 211-222.
} 